\title{
Tracheal Infection due to Corynebacterium striatum in a Female Patient: A Case Report
}

\section{Bir Kadın Hastada Corynebacterium striatum bağlı Trakeal Enfeksiyon: Olgu Sunumu}

Panagiota Xaplanteri', Efstratios N. Koletsis², Christos Prokakis², Iris Spiliopoulou', Dimitrios Dougenis ${ }^{3}$, Fevronia Kolonitsiou'

\section{Abstract}

Nondiphtherial corynebacteria commonly colonize as normal flora on human skin and mucous membranes, and represent an emerging opportunistic pathogen for immunocompromised or critically ill patients. Corynebacterium striatum has seldom been reported as a human pathogen. Here we present the case of a 62-year-old Caucasian female patient who was previously hospitalized in the Intensive Care Unit, and who attended the emergency department with worsening dyspnea and inspiratory wheezing. The findings of a thorough examination, laboratory tests and imaging were consistent with tracheal stenosis, inflammation related to a previous tracheostomy and a submerged thyroid goiter. A multi-drug resistant $C$. striatum strain was isolated. The patient was treated with a subtotal thyroidectomy, tracheal resection and tigecycline. Postoperative recovery was complicated by a trauma infection treated with open drainage and antibiotics, and after a long recovery period, the patient was discharged home without further complications.

Key words: Corynebacterium striatum, multi-drug resistance, opportunistic infections, tigecycline.
Özet

Nondifteriyal Corynebacteria insan cildi ve mukozalarında sıklıkla normal flora olarak kolonize olur. İmmün yetmezliği ya da kritik hastalığı olanlarda fırsatçı patojenler olarak ortaya çıkar. Corynebacterium striatum insanda, nadiren patojen olarak bildirilmiştir. Bu yazıda, daha önce hastahanenin Acil Servis'ine giderek artan dispne ve inspiratuvar wheezing bulgularıyla başvuran ve Yoğun Bakım Servisinde yatırılarak tedavi gören 62 yaşında beyaz kadın hasta sunulmuştur. Muayene, laboratuar ve görüntüleme bulguları, guatr'a bağlı eski trakeostomi sonrası gelişen enfeksiyonun neden olduğu trakeal stenoz ile uyumluydu. Kültürde çoklu antibiyotiklere dirençli C. striatum izole edildi. Hasta subtotal tiroidektomi, trakeal rezeksiyon ve tigecycline ile tedavi edildi. Ameliyat sonrası dönemde, açık drenaj ve antibiyotiklerle tedavi edilen travmatik bir enfeksiyonun neden olduğu komplikasyon gelişti. Uzun süren iyileşme döneminde başkaca komplikasyonlar olmaksızın taburcu edildi.

Anahtar Sözcükler: Corynebacterium striatum, multiple-ilaç direnci, fırsatçı enfeksiyonlar, tigecycline.
'Department of Microbiology, University General Hospital of Patras, Greece

${ }^{2}$ Department of Cardiothoracic Surgery, University General Hospital of Patras, Greece

${ }^{3}$ Department of Cardiac Surgery, Attikon University Hospital of Athens, Greece
'Patrasya Üniversitesi Genel Hastanesi, Mikrobiyoloji Anabilim Dalı, Yunanistan

2Patrasya Üniversitesi Genel Hastanesi Kalp ve Damar Cerrahisi Anabilim Dalı, Yunanistan

${ }^{3}$ Atina Kalp Cerrahisi Bölümü Attikon Üniversitesi Hastanesi, Yunanistan

Submitted (Başvuru tarihi): 06.12.2018 Accepted (Kabul tarihi): 14.02.2019

Correspondence (iletişim): Fevronia Kolonitsiou, Department of Microbiology, University General Hospital of Patras, Greece

e-mail: kolonits@upatras.gr 
Nondiphtherial Corynebacteria are a common flora of the human skin and mucous membranes. They rarely represent a risk for clinical infections in immunocompromised or critically ill patients. Corynebacterium striatum has seldom been reported as a human pathogen (1). Here we present the case of a 62-year-old Caucasian female patient who was previously hospitalized in the Intensive Care Unit (ICU), and who attended the emergency department due to worsening dyspnea and inspiratory wheezing. Laboratory and imaging findings revealed tracheal stenosis and a submerged thyroid goiter. A culture of the tracheal fluid obtained following a surgical intervention proved positive for a multi-drug resistant $C$. striatum strain.

\section{CASE}

A 62-year-old Caucasian female patient with a medical history of polycythemia vera, diabetes mellitus, hypertension, thyroid goiter and ICU hospitalization six months previously attended the Emergency Department of our hospital complaining of worsening dyspnea for the past two months and inspiratory wheezing. Laboratory tests revealed a white blood cell count of 15.580 cells $/ \mathrm{mm} 3$, with $87.8 \%$ neutrophils, elevated $\mathrm{C}$-reactive protein levels (2.39 U/L, normal values $<0.5 \mathrm{U} / \mathrm{L})$, glucose $481 \mathrm{mg} / \mathrm{dL}$ (normal values $75-115 \mathrm{mg} / \mathrm{dL}$ ), urea $69 \mathrm{mg} / \mathrm{dL}$ (normal values $15-54 \mathrm{mg} / \mathrm{dL}$ ), creatinine $0.8 \mathrm{mg} / \mathrm{dL}$ (normal values $0.9-1.6 \mathrm{mg} / \mathrm{dL}$ ), sodium $129.6 \mathrm{mmol} / \mathrm{L}$ (normal values $134-152 \mathrm{mmol} / \mathrm{L}$ ), potassium $4.2 \mathrm{mmol} / \mathrm{L}$ (normal values $3.8-5.5 \mathrm{mmol} / \mathrm{L}$ ), aminotransferase $18 \mathrm{U} / \mathrm{L}$ (normal values 5-40 U/L) and alanine aminotransferase 19 $\mathrm{U} / \mathrm{L}$ (normal values 5-40 U/L).

A computed tomography of the neck and chest revealed a submerged thyroid goiter that caused the tracheal stenosis. The surrounding tissue of the trachea, which was probably of inflammatory origin, had a similar enhancement and was associated with the thyroid gland, most possibly due to the former tracheostomy during the patient's previous hospitalization in the ICU. Bronchoscopy revealed stenosis and deformation of the trachea, as well as mucosal hyperemia (Figure 1). A thyroid scan scintigraphy confirmed the presence of a submerged thyroid gland. The patient underwent emergency surgery, during which macroscopic findings were a slightly narrowed trachea, $2 \mathrm{~cm}$ distal to the cricoid cartilage for a length of $2-2.5 \mathrm{~cm}$, and a swollen tracheal wall with a granulomatous appearance and dirty fluid therein. After a subtotal thyroidectomy was carried out, the trachea was opened, cultures of the fluid were obtained and a tracheal resec- tion of the stenotic segment with end-to-end anastomosis was performed. No microscopic details of the tracheal material were available from the pathology department. The culture samples were inoculated onto blood and McConkey agar media and incubated overnight at $37^{\circ} \mathrm{C}$. The growth of cream-colored non-hemolytic colonies was observed in the blood agar medium. Gram staining revealed Gram-positive non-spore forming bacilli. A catalase test was positive. The identification of the isolate was made via the Crystal BD BBL ${ }^{\mathrm{TM}}$ Crystal $^{\mathrm{TM}}$ identification system for Gram positive bacteria (BD Diagnostics, Le Pont de Claix, France) and proved to be C. striatum (bionumber 0464041141, Becton Dickinson Diagnostics, Franklin Lakes, New Jersey, USA). Antibiotic susceptibility testing was initially performed via the disk diffusion method for penicillin, clindamycin, tetracycline, rifampicin, ciprofloxacin and vancomycin, in accordance with EUCAST guidelines (2). As the stain proved to be resistant to all the aforementioned antibiotics, a gradient method (Etest, bioMerieux) was applied for a minimum inhibitory concentration (MIC) determination of vancomycin, tigecycline, linezolid and daptomycin. The strain was subsequently found to be resistant to vancomycin (MIC $=>256$ $\mathrm{mg} / \mathrm{L})$, and susceptible to tigecycline $(\mathrm{MIC}=0,032 \mathrm{mg} / \mathrm{L})$, linezolid $(\mathrm{MIC}=0.125 \mathrm{mg} / \mathrm{L})$ and daptomycin $(\mathrm{MIC}=0.19 \mathrm{mg} / \mathrm{L})$. The patient was treated with tigecycline $50 \mathrm{mg}$ twice daily after a loading dose of $100 \mathrm{mg}$. Postoperative recovery was complicated by a trauma infection (multidrug resistant Klebsiella pneumoniae), which was treated with open drainage and intravenous antibiotics. After a long-standing recovery of 28 days, the patient was discharged home without further complications.

\section{DISCUSSION}

Nondiphtherial Corynebacteria (Dyphtheroids) are aerobic, Gram-positive, non-spore forming, catalase-positive rods that are usual colonizers of the human skin and mucous membranes. Certain species, including Corynebacterium striatum, C. amycolatum, C. minutissimum, C. xerosis, C. jeikeium, C. macginleyi, C. urealyticum, C. pseudodiphtheriticum and C. freneyi, have appeared recently as opportunistic pathogens in immunocompromised patients, in patients with hematologic malignances and in the critically ill $(3,4)$. Corynebacterium striatum colonizes prosthetic devices, catheter tips and ventilator tubes (3), and so most cases where C. striatum is isolated as the culprit pathogen are nosocomial infections involving the exit sites of central venous catheters, conjunctivitis, 
chorioamnionitis, peritonitis and pyogenic granuloma (1), catheter related blood stream infections (4), pleuropneumonia, meningitis, endocarditis, osteomyelitis and arthritis (5). Most strains of C. striatum described earlier in literature that caused human infections were susceptible to vancomycin, linezolid, tigecycline, imipenem, ciprofloxacin and aminoglycosides, resistant to penicillin $G$, but susceptible to other beta-lactams $(1,6)$. In most recent studies, mainly those detailing respiratory infections resulting from $C$. striatum, all isolates have shown multiple antibiotic resistance phenotypes (3).

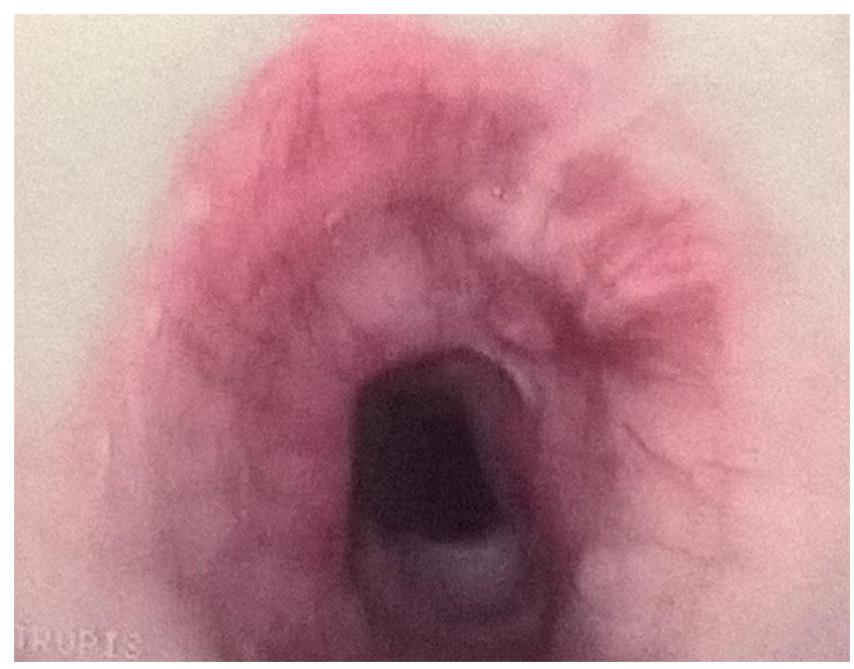

Figure 1: A bronchoscopic view of the mucosal hyperemia

Prolonged hospitalization, mechanical ventilation and use of broad-spectrum antibiotics predispose patients to multidrug resistant $C$. striatum infections $(7,8)$. There is supporting evidence that the microorganism has high adaptability to antibiotic pressure. The molecular mechanisms of resistance described to date still remain to be elucidated. Most studies involve the plasmid pTP10 (3). It would seem that the main mode of bacterium transmission is via person-to-person contact, or via inhalation devices (3). Our patient had been hospitalized in the ICU six months prior to admission, and her underlying diseases and the use of broad-spectrum antibiotics, combined with the tracheostomy performed in the ICU, led to colonization and tracheal infection by this multi-drug resistant strain of C. striatum.

As the antimicrobial susceptibility of $C$. striatum is usually unpredictable, susceptibility tests are necessary for the selection of the best treatment (9), although the optimal therapy remains controversial (6). Our patient was successfully treated with tigecycline.

\section{CONCLUSION}

C. striatum is an emerging multidrug resistant opportunistic nosocomial pathogen. As its main course of transmission is via person-to-person contact and colonization of mechanical airway ventilation, it should be considered as a pathogen of a respiratory tract infection in critically ill patients with prolonged hospitalization and immunosuppression. To the best of our knowledge, this is the first case of tracheal infection due to $C$. striatum described worldwide.

\section{CONFLICTS OF INTEREST}

None declared.

\section{AUTHOR CONTRIBUTIONS}

Concept - I.S., D.D., F.K., E.N.K., P.X., C.P.; Planning and Design - I.S., D.D., F.K., E.N.K., P.X., C.P.; Supervision - F.K., E.N.K., C.P., I.S., D.D., P.X.; Funding - P.X., E.N.K., C.P., F.K.; Materials - P.X., E.N.K., C.P., F.K.; Data Collection and/or Processing - I.S., D.D., F.K., E.N.K., P.X., C.P.; Analysis and/or Interpretation - P.X., E.N.K., C.P., F.K.; Literature Review - F.K.; Writing - P.X., I.S., F.K.; Critical Review - I.S., D.D., F.K.

\section{YAZAR KATKILARI}

Fikir - I.S., D.D., F.K., E.N.K., P.X., C.P.; Tasarım ve Dizayn - I.S., D.D., F.K., E.N.K., P.X., C.P.; Denetleme F.K., E.N.K., C.P., I.S., D.D., P.X.; Kaynaklar - P.X., E.N.K., C.P., F.K.; Malzemeler - P.X., E.N.K., C.P., F.K.; Veri Toplama ve/veya İşleme - I.S., D.D., F.K., E.N.K., P.X., C.P.; Analiz ve/veya Yorum - P.X., E.N.K., C.P., F.K.; Literatür Taraması - F.K.; Yazıyı Yazan - P.X., I.S., F.K.; Eleştirel İnceleme - I.S., D.D., F.K.

\section{REFERENCES}

1. Watkins DA, Chahine A, Creger RJ, Jacobs MR, Lazarus HM. Corynebacterium striatum: a diphtheroid with pathogenic potential. Clin Infect Dis 1993; 17:21-5. [CrossRef]

2. The European Committee on Antimicrobial Susceptibility Testing. Breakpoint tables for interpretation of MICs and zone diameters. Version 8.1, 2018. http://www.eucast.org." Access date: August 10, 2018). Place of access: www.eucast.org.

3. Renom F, Gomila M, Garau M, Gallegos MD, Guerrero D, Lalucat J, et al. Respiratory infection by Corynebacterium striatum: epidemiological and clinical determinants. New Microbes New Infect 2014; 2:106-14. [CrossRef] 
4. Daisuke U, Oishi T, Yamane K, Terada K. Corynebacterium striatum bacteremia associated with a catheterrelated blood stream infection. Case Rep Infect Dis 2017; 2017:2682149. [CrossRef]

5. Topić A, Civljak R, Butić I, Gužvinec M, Kuzman I. Relapsing bacteremia due to Corynebacterium striatum in a patient with peripheral arterial disease. Pol J Microbiol 2015; 64:295-8. [CrossRefl

6. Chen FL, Hsueh PR, Teng SO, Ou TY, Lee WS. Corynebacterium striatum bacteremia associated with central venous catheter infection. J Microbiol Immunol Infect 2012; 45:255-8. [CrossRef]

7. Leonard RB, Nowowiejski DJ, Warren JJ, Finn DJ, Coyle MB. Molecular evidence of person-to-person transmis- sion of a pigmented strain of Corynebacterium striatum in intensive care units. J Clin Microbiol 1994; 32:164-9.

8. Brandenburg $A H$, van Belkum $A$, van Pelt $C$, Bruining $H A$, Mouton JW, Verbrugh HA. Patient-to-patient spread of a single strain of Corynebacterium striatum causing infections in a surgical intensive care unit. J Clin Microbiol 1996; 34:2089-94.

9. Soriano F, Zapardiel J, Nieto E. Antimicrobial susceptibilities of Corynebacterium species and other non-sporeforming gram-positive bacilli to 18 antimicrobial agents. Antimicrob Agents Chemother 1995; 39:208-14. [CrossRef] 